\title{
Influence of arterial hypotension on fractional flow reserve measurements
}

\author{
Florence Verdier-Watts ${ }^{1}$, MD; Gilles Rioufol ${ }^{1,2 *}, \mathrm{MD}, \mathrm{PhD}$; Nathan Mewton ${ }^{2}, \mathrm{MD}, \mathrm{PhD}$; Ingrid Sanchez ${ }^{1}$, MD; \\ Lisa Green ${ }^{1}, \mathrm{MD}$; Eric Bonnefoy-Cudraz ${ }^{1}, \mathrm{MD}, \mathrm{PhD}$; Gérard Finet ${ }^{1,2}, \mathrm{MD}, \mathrm{PhD}$ \\ 1. Interventional Cardiology Department, Hospices Civils de Lyon, Bron, France; 2. INSERM U1060, CarMeN, SFR Lyon-Est \\ (CNRS UMS3453 - INSERM US7), Lyon, France
}

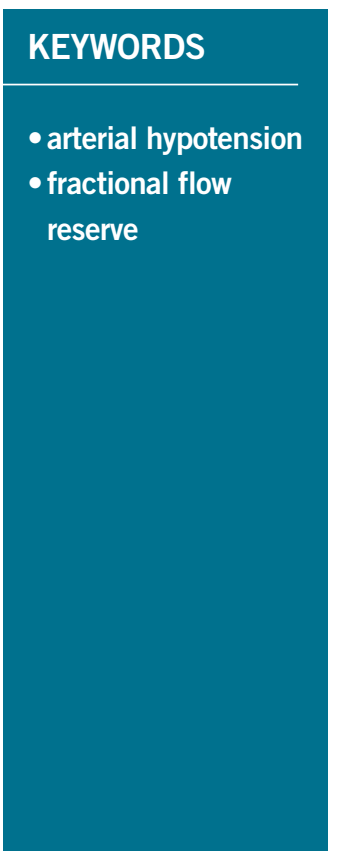

\begin{abstract}
Aims: To assess fractional flow reserve (FFR) variability in case of arterial hypotension in the clinical setting. FFR measurement is supposed to be independent of haemodynamics; there is, however, a strong relationship between trans-stenotic pressure variation and coronary flow. Non-clinical models suggest an inverse relationship between arterial pressure and FFR, but no clinical data have as yet confirmed this hypothesis.

Methods and results: In case of arterial hypotension (mean arterial pressure $[\mathrm{Pa}] \leq 80 \mathrm{mmHg}$ ) during routine clinical FFR measurement $\left(\mathrm{FFR}_{1}\right)$, a second measurement $\left(\mathrm{FFR}_{2}\right)$ was performed after pressure normalisation by $0.5 \mathrm{mg}$ IV phenylephrine. Fourteen intermediate chronic stenoses ( $\% \mathrm{DS} 58 \pm 21 \%, \mathrm{FFR}_{1}=0.81 \pm 11$ ) in 12 male patients showed $70 \pm 10 \mathrm{mmHg}$ Pa at the time of measurement. After phenylephrine, Pa increased to $101 \pm 14 \mathrm{mmHg}$ and $\mathrm{FFR}_{2}$ decreased to $0.75 \pm 12(\mathrm{p}<0.001)$ without heart rate variation. After Pa elevation, $40 \%$ of cases with $\mathrm{FFR}_{1}>0.80$ changed to $\mathrm{FFR}_{2} \leq 0.80$.
\end{abstract}

Conclusions: In the present study, in case of arterial hypotension, FFR decreased with rising pressure. Whether repeated FFR measurement after haemodynamic normalisation is of clinical benefit remains at this point speculative and should be validated in a larger data set.

\footnotetext{
*Corresponding author: Interventional Cardiology Dept, Hôpital Cardiologique - Hospices Civils de Lyon, 28 avenue Lépine, 69677 Bron Cedex, France. E-mail: gilles.rioufol@univ-lyon1.fr
} 


\section{Abbreviations}

$\begin{array}{ll}\text { CFR } & \text { coronary flow reserve } \\ \text { FFR } & \text { fractional flow reserve } \\ \text { IC } & \text { intracoronary } \\ \text { IV } & \text { intravenous } \\ \text { LV } & \text { left ventricular } \\ \text { Pa } & \text { mean arterial pressure } \\ \text { Pzf } & \text { zero-flow pressure }\end{array}$

\section{Introduction}

Fractional flow reserve assesses the functional impact of coronary stenosis, and a threshold of 0.75 corresponds to a significant stenosis $^{1}$ : due to a limited grey zone, FFR $\leq 0.80$ is the recommended threshold for treatment ${ }^{2}$. Compared to other functional assessment measurements such as coronary flow reserve, FFR, based on pressure measurement under maximal hyperaemia, is more reproducible and moreover independent of haemodynamic variables such as heart rate and arterial pressure ${ }^{3}$. Compared to angiography, FFR is associated with better prognosis in angioplasty ${ }^{4,5}$. Its ease of implementation and reliability make it a routine clinical component of diagnostic coronarography, recommended in the absence of prior non-invasive testing ${ }^{6,7}$.

In case of stenosis, however, there is a quadratic relation between trans-stenotic pressure variation and coronary flow rate ${ }^{8}$, and modelling revealed an impact of arterial pressure on FFR values ${ }^{9,10}$, especially for those approximating the clinical cut-off threshold. In view of the immediate therapeutic impact of FFR and the wide inter-subject haemodynamic variation routinely observed in the cathlab, the present study sought to assess variation in FFR measurement in case of arterial hypotension at the time of examination.

\section{Methods PATIENTS}

This prospective study included patients solely referred for invasive assessment of stable or stabilised angina and showing arterial hypotension during FFR measurement, with the following additional inclusion criteria: normal left ventricular (LV) systolic function, with no signs of ventricular hypertrophy on ECG and/or cardiac echo, no history of acute coronary syndrome in the artery studied by FFR, and no symptoms of heart failure. Vasovagal syndrome was an exclusion criterion.

\section{CORONAROGRAPHY AND FFR MEASUREMENT}

Coronarography used either a radial or a femoral approach, with $1 \mathrm{mg}$ intracoronary (IC) nitrate in case of coronary atherosclerosis. Coronary lesion angiography was analysed visually and quantitatively (Centricity ${ }^{\circledR}$ CA1000; GE Healthcare, Little Chalfont, Buckinghamshire, UK). FFR was measured routinely when clinically indicated, using a 5 or 6 Fr catheter after intravenous injection of 5,000 IU heparin and $500 \mathrm{mg}$ aspirin. A 0.014" PressureWire ${ }^{\mathrm{TM}}$ Certus $^{\mathrm{TM}}$ (St. Jude Medical, St. Paul, MN, USA) was carefully calibrated and then passed through the stenosis. Hyperaemia was achieved by IC injection of 100 to $150 \mu \mathrm{g}$ adenosine ahead of the first FFR measurement $\left(\mathrm{FFR}_{1}\right)$. Curve equalisation was systematically checked at end-of-procedure on withdrawal of the FFR wire, with exclusion in case of $\geq 0.02$ deviation.

\section{ARTERIAL HYPOTENSION AT FFR MEASUREMENT AND ELEVATED ARTERIAL PRESSURE}

Before adenosine injection, patients with normal clinical tolerance and no vasovagal syndrome were included in case of mean $\mathrm{Pa}$ $\leq 80 \mathrm{mmHg}$ at FFR measurement $\left(\mathrm{FFR}_{1}\right)$. After pressure elevation by intravenous injection of $0.5 \mathrm{mg}$ phenylephrine, an alpha 1-adrenergic vasoconstrictor, a second FFR measurement $\left(\mathrm{FFR}_{2}\right)$ was made five minutes after arterial pressure stabilised.

FFR variation slope, in $100 \mathrm{mmHg}^{-1}$, was calculated from the $\mathrm{FFR}_{2}-\mathrm{FFR}_{1}$ differential for the differential mean aortic pressure values $\left(\mathrm{Pa}_{2}-\mathrm{Pa}_{1}\right)$ obtained before and after phenylephrine injection.

\section{STATISTICS}

Due to the small sample size, statistical assumptions for normality were checked using the Shapiro-Wilk test. All continuous variables (heart rate, arterial pressure and FFR) showed a $\mathrm{W}$ value between 0.915 and 0.970 , above the threshold of 0.874 set for $\mathrm{p}=0.05$, suggesting normal distribution. Data were then expressed as means or mean \pm standard deviation, depending on the type of variable. The paired Wilcoxon signed-rank test for continuous variables and Fisher's exact test for categorical variables were used. The significance threshold was set at $\mathrm{p}<0.05$.

\section{Results}

Out of 415 consecutive coronary angiographies using FFR, 12 male patients with 14 intermediate grade coronary stenoses $(58 \pm 21 \%$ diameter stenosis) meeting the inclusion criteria were assessed prospectively (3.3\% of the population). The study group's clinical characteristics were typical of a coronary patient population, and the studied artery was the left anterior descending (LAD) in half of the cases (Table 1).

No clinically significant AV block occurred with adenosine injection. At first FFR measurement $\left(\right.$ FFR $_{1}$ ), mean arterial pressure was $70 \pm 10 \mathrm{mmHg}$ (typically, systolic arterial pressure was $\leq 100 \mathrm{mmHg}$ ), with six lesions (43\%) showing $\mathrm{FFR}_{1} \leq 0.80$. After pressure elevation to a mean $101 \pm 14 \mathrm{mmHg}$ (systolic arterial pressure rose after phenylephrine injection to $140-150 \mathrm{mmHg}$ ), all FFR values $\left(\mathrm{FFR}_{2}\right)$ fell $(0.75 \pm 12$ vs. $0.81 \pm 11 ; \mathrm{p}<0.001)$, with 10 (71\%) showing $F_{2 F R} \leq 0.80$ ( $<<0.05$ vs. FFR ; Table 2). The slope of FFR decrease was $-20.8 \pm 12.5 .100 . \mathrm{mmHg}^{-1}$. Interestingly, baseline $\mathrm{Pd} / \mathrm{Pa}$, before hyperaemia induction, showed the same relationship on a smaller scale (slope $=-9.1 \pm 13.0 .100 . \mathrm{mmHg}^{-1}$ ). The four lesions with FFR crossover coincided with the lowest $\mathrm{Pa}_{1}(65 \pm 7$ vs. $73 \pm 4 \mathrm{mmHg}$ ), and two lesions had $\mathrm{FFR}_{1}>0.85$ that decreased to $<0.75$ after phenylephrine. Overall, in case of arterial hypotension, a $31 \pm 16 \mathrm{mmHg}$ pressure rise reduced FFR by $0.05 \pm 0.03$, downgrading $40 \%$ of lesions initially considered functionally nonsignificant (Figure 1). The fall in FFR tended to be greater in angiographically more severe stenoses $\left(-26.6 \pm 14.2 .100 . \mathrm{mmHg}^{-1}\right.$ for 
Table 1. Demographic data.

\begin{tabular}{|c|c|c|}
\hline \multicolumn{2}{|l|}{ Male, n (\%) } & $12(100)$ \\
\hline \multicolumn{2}{|l|}{ Age, yrs } & $59 \pm 11$ \\
\hline \multicolumn{2}{|l|}{ LVEF, \% } & $54 \pm 10$ \\
\hline \multicolumn{2}{|l|}{ Tobacco, n (\%) } & $9(75)$ \\
\hline \multicolumn{2}{|c|}{ Hypercholesterolaemia, n (\%) } & $6(50)$ \\
\hline \multicolumn{2}{|c|}{ Hypertension, n (\%) } & $5(42)$ \\
\hline \multicolumn{2}{|c|}{ LV hypertrophy, n (\%) } & $0(0)$ \\
\hline \multicolumn{2}{|l|}{ Diabetes, n (\%) } & $2(16)$ \\
\hline \multicolumn{2}{|c|}{ History of MI, n (\%) } & $8(67)$ \\
\hline \multicolumn{2}{|c|}{ Stable angina, $\mathrm{n}(\%)$} & $9(75)$ \\
\hline \multicolumn{2}{|c|}{ History of $\mathrm{PCl}, \mathrm{n}(\%)$} & $7(58)$ \\
\hline \multicolumn{2}{|c|}{ Beta-blocker, n (\%) } & $8(67)$ \\
\hline \multicolumn{2}{|l|}{ Antiplatelet, n (\%) } & $11(92)$ \\
\hline \multicolumn{2}{|l|}{ ARB, n (\%) } & $7(58)$ \\
\hline \multicolumn{2}{|l|}{ Statin, n (\%) } & $11(92)$ \\
\hline \multirow{4}{*}{$\begin{array}{l}\text { Coronary disease, } \\
n(\%)\end{array}$} & Atherosclerosis & $1(9)$ \\
\hline & 1 vessel & $7(58)$ \\
\hline & 2 vessels & $4(33)$ \\
\hline & 3 vessels & $0(0)$ \\
\hline \multicolumn{2}{|c|}{ Explored artery, n (\%) } & 14 \\
\hline \multicolumn{2}{|l|}{ LAD } & $7(50)$ \\
\hline \multicolumn{2}{|l|}{ LCx } & $3(21)$ \\
\hline \multicolumn{2}{|l|}{$\mathrm{RCA}$} & $4(29)$ \\
\hline \multicolumn{2}{|l|}{ \%DS (visual) } & $58 \pm 21$ \\
\hline \multicolumn{2}{|l|}{ Ref $\mathrm{D}, \mathrm{mm}$} & $2.8 \pm 0.4$ \\
\hline \multicolumn{2}{|l|}{$\% D S(Q C A)$} & $43 \pm 14$ \\
\hline \multicolumn{2}{|l|}{ Length, mm } & $10 \pm 4$ \\
\hline \multicolumn{2}{|l|}{ Mean AP, mmHg } & $69 \pm 7$ \\
\hline \multicolumn{2}{|l|}{ Heart rate, bpm } & $65 \pm 13$ \\
\hline
\end{tabular}

ARB: angiotensin II receptor blocker; DS: diameter stenosis; EF: ejection fraction; LAD: left anterior descending artery; LCx: circumflex artery; $\mathrm{MI}$ : myocardial infarction; RCA: right coronary artery

$70-90 \%$ stenosis vs. $-16.4 \pm 9.7 .100 . \mathrm{mmHg}^{-1}$ for $40-70 \%$ stenosis, $\mathrm{p}=0.17$ ) and for lower initial arterial pressure $(\mathrm{p}=0.12$; Figure 2). Overall, the observed variability in FFR was $7 \pm 4 \%$, and reached $8 \pm 3 \%$ in case of $70-90 \%$ stenosis.

\section{Discussion}

\section{FFR INDEPENDENCE AND HAEMODYNAMICS}

FFR is classically considered to be independent of haemodynamic conditions $^{8}$, with overall inter-subject variation at $4 \%{ }^{3}$, much lower than for coronary flow reserve (approx. 18\%). De Bruyne et al demonstrated that variation with change in Pa was only $3.3 \%{ }^{3}$. In case of arterial hypotension ( $\mathrm{Pa} \leq 80 \mathrm{mmHg}$ ), overall FFR variation is twice as great as usual, especially in the most angiographically severe stenoses $(8 \pm 3 \%)$.

FFR validation studies in humans examined variation under reduction from $100 \pm 9$ to $79 \pm 6 \mathrm{mmHg} \mathrm{Pa}$ induced by nitroprusside perfusion ${ }^{3}$. This vasodilator, however, induced reflex tachycardia ( $78 \pm 10$ to $89 \pm 12$ bpm increase in heart rate: $+14 \%$; $p<0.05$ ),

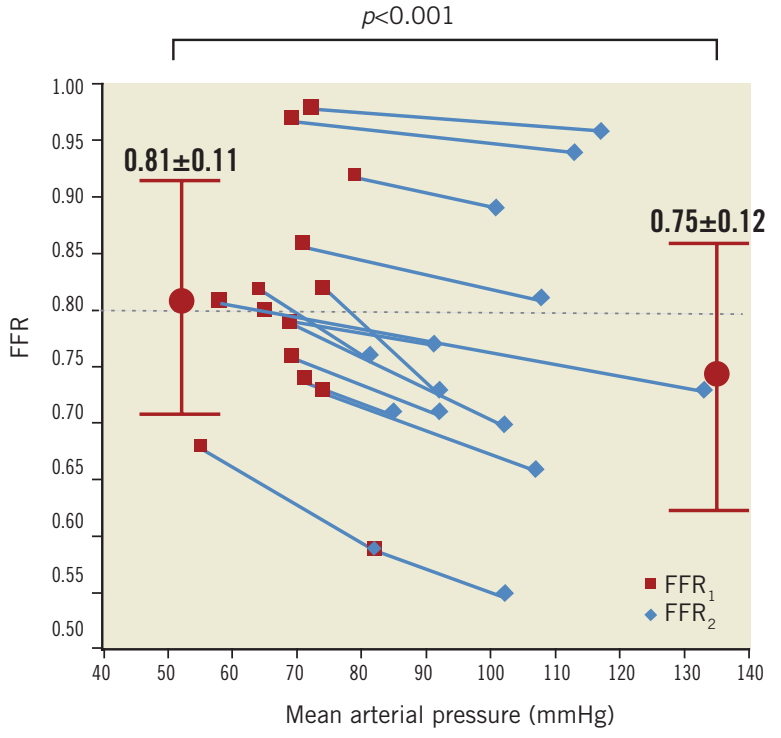

Figure 1. Relationship between FFR (mean $\pm S D)$ and mean arterial pressure in assessment of a given stenosis.

Table 2. Haemodynamics and FFR variations.

\begin{tabular}{|l|c|c|c|}
\hline & Initial & $\begin{array}{c}\text { Post } \\
\text { phenylephrine }\end{array}$ & $\boldsymbol{p}$ \\
\hline Heart rate, bpm & $65 \pm 13$ & $62 \pm 17$ & 0.39 \\
\hline $\mathrm{Pa}$ baseline, $\mathrm{mmHg}$ & $70 \pm 10$ & $101 \pm 14$ & 0.001 \\
\hline $\mathrm{Pd} / \mathrm{Pa}$ baseline & $0.93 \pm 0.05$ & $0.90 \pm 0.05$ & 0.01 \\
\hline Hyperaemic $\mathrm{Pa}, \mathrm{mmHg}$ & $69 \pm 7$ & $100 \pm 15$ & 0.001 \\
\hline FFR & $0.81 \pm 11$ & $0.75 \pm 12$ & 0.001 \\
\hline FFR $\leq 0.80, \mathrm{n}(\%)$ & $6(43)$ & $10(71)$ & 0.04 \\
\hline
\end{tabular}

probably impacting on the $\mathrm{Pd}-\mathrm{Pv} / \mathrm{Pa}-\mathrm{Pv}$ ratio ${ }^{9}$. Experimental studies in dogs also used nitroprusside ${ }^{11}$, but did not mention heart rate variation. In the present study, Pa variation was obtained without altering heart rate (FC1 $65 \pm 13$ vs. FC2 $62 \pm 17$ bpm; p=NS), using phenylephrine, which has no chronotropic or inotropic effect ${ }^{12}$.

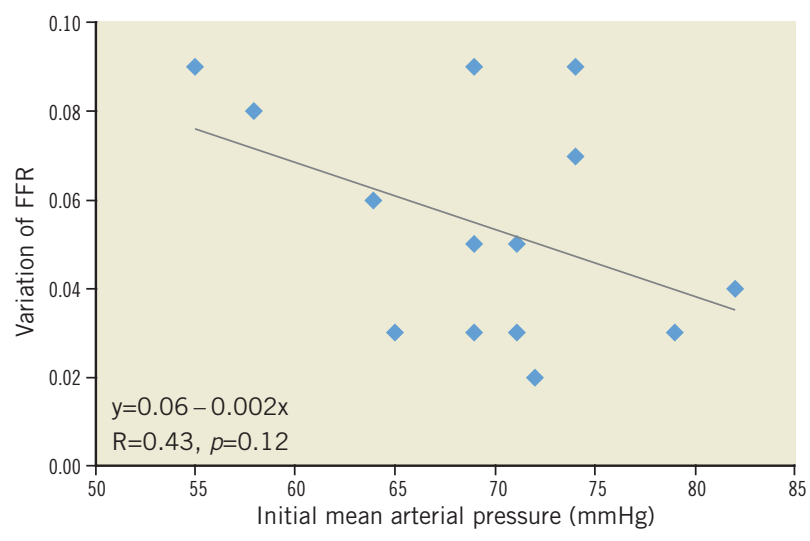

Figure 2. Relationship of FFR variation (expressed as the difference: $F F R_{1}-F F R_{2}$ ) according to initial arterial pressure. 
However, $\alpha$-agonist receptors are present in the coronary circulation tree and could decrease coronary flow in case of coronary stenosis ${ }^{13}$. Moreover, in case of mild stenosis, intracoronarily injected phentolamine, an $\alpha$-agonist blocker, has been shown to decrease FFR slightly (from $0.79 \pm 0.02$ to $0.77 \pm 0.02 ; \mathrm{p}=0.03$ ) ${ }^{14}$. From the point of view of coronary and myocardial physiology, phenylephrine should therefore be able to increase FFR. Despite this, the present results showed that phenylephrine injection decreased FFR significantly, reinforcing the pivotal role of arterial pressure.

It is noteworthy that the present $\mathrm{Pa}$ values were lower than those reported with nitroprusside by De Bruyne et al $(69 \pm 7 \mathrm{mmHg}$ vs. $79 \pm 6 \mathrm{mmHg}$ ), which may explain why no FFR variation was initially observed ${ }^{3}$. The paradoxical re-elevation found in FFR values when $\mathrm{Pa}$ was reduced by $58 \pm 15 \mathrm{mmHg}$, in a dose-ranging study of adenosine IV, provides further support ${ }^{15}$.

Patients showing arterial hypotension during FFR measurement are rare (around 3\% of the present series) but are nevertheless regularly encountered. The aetiology of this hypotension is not obvious, but certainly involves fasting, isosorbide mononitrate injection and continuation of beta-blockers and/or angiotensin receptor blockers.

\section{MODEL CONFIRMATION}

Using a resistive model of epicardial coronary stenosis, Siebes et al analysed the independence of FFR with respect to haemodynamic conditions $^{9}$ and found overestimation when Pa was reduced or zero-flow pressure (Pzf) increased. FFR was independent of $\mathrm{Pa}$ only for $\mathrm{Pzf}=0$; in case of stenosis, it was Pa-dependent, due to the quadratic component of pressure loss according to flow. The present clinical findings are in agreement with these data; in Siebes et al's simulations ${ }^{9}$, the FFR variation slope according to $\mathrm{Pa}$ could be calculated for a given stenosis: between $50 \%$ and $80 \%$ stenosis, the slope was about $-16.100 . \mathrm{mmHg}^{-1}$, very close to the present value of $-20.8 \pm 12.5 .100 . \mathrm{mmHg}^{-1}$.

Claessens et al modelled the same type of $\mathrm{Pa} / \mathrm{FFR}$ interaction ${ }^{10}$ and also found FFR overestimation, by up to $56 \%$, with Pzf elevation. Pzf can be estimated in the clinical setting only by using intracoronary Doppler probe ${ }^{16}$ but not by FFR. Pzf has, however, frequently been put at $30-40 \mathrm{mmHg}^{16}$.

\section{CLINICAL IMPLICATIONS}

Functional analysis of epicardial coronary stenosis is closely bound to physiological self-regulation phenomena operating at perfusion pressures ranging overall from about $60-70$ to $150 \mathrm{mmHg}^{8}$. If functional assessment is performed at hypotension approximating the lower threshold of self-regulation, then flow change under hyperaemia will be moderate in absolute terms, increasing the risk of relative error. The larger difference between FFR 1 and FFR 2 noted for the lowest baseline arterial pressure, also not statistically significant, probably reinforces the need for cautious interpretation of FFR in case of arterial hypotension.

To this must be added the intrinsic limits of FFR in terms of $\mathrm{Pa}$, and the uncertainty as to Pzf, exacerbating the risk of overestimation. The present study was based on an arbitrary threshold of $80 \mathrm{mmHg}$, derived from the generally accepted self-regulatory range, and individual variability could exist. To date, no specific guidelines are available on the optimal arterial pressure range for FFR measurement. In theory, hypotension may lead to underestimation of stenosis severity; however, as yet, no clinical data support this.

In the present study, it was decided to use phenylephrine, to increase blood pressure rapidly; there is no obvious reason why a similar $\mathrm{Pa}$ increase should not be achieved by other means (e.g., fluid perfusion), although a validation similar to the present one should in that case be undertaken.

With FFR increasingly used in routine practice, it is important: 1) to detect clinical situations of arterial hypotension; and 2) in case of arterial hypotension, to repeat measurement after optimising the haemodynamic conditions.

\section{Limitations}

The sample size was small in this study, even if FFR was observed as falling after $\mathrm{Pa}$ elevation in all cases, suggesting a significant physiological relationship between Pa and FFR. Secondly, hyperaemia was obtained by IC adenosine, and extrapolation to IV adenosine measurements is only speculative.

Moreover, measurement was performed during routine practice, and left ventricular filling and venous pressure $(\mathrm{Pv})$ data were not available. Although LV function was normal and no symptom of heart failure was observed, a slight effect of Pv cannot definitely be excluded.

Finally, microcirculatory resistance was not estimated. Two measurement points, however, cannot demonstrate a linear relationship, nor do the models support this. The present slope measurement enables comparison between clinical and model-derived data only along the linear part of the curve.

\section{Conclusions}

In this study, in case of arterial hypotension, FFR decreased with rising pressure. This observation confirms modelling data and may raise the issue of the independence of FFR with respect to pressure in a borderline physiological situation; this, however, needs to be confirmed in further studies. Whether repeated FFR measurement after haemodynamic normalisation could show clinical benefit remains at this point speculative and should be validated in a larger data set.

\section{Impact on daily practice}

Fractional flow reserve is the standard of care for coronary stenosis assessment, especially when previous non-invasive tests are lacking, and is reported to be independent of haemodynamics. We show, however, that, in the case of borderline physiological arterial pressure (mean arterial pressure $\leq 80 \mathrm{mmHg}$ ), FFR is inversely related to $\mathrm{Pa}$ with overestimation of the FFR value in the case of arterial hypotension, leading to underestimation of the explored coronary stenosis. In the case of arterial hypotension, we suggest repeating measurement after optimising the haemodynamic conditions. 


\section{Conflict of interest statement}

The authors have no conflicts of interest to declare.

\section{References}

1. Pijls NH, De Bruyne B, Peels K, Van Der Voort PH, Bonnier HJ, Bartunek J, Koolen JJ. Measurement of fractional flow reserve to assess the functional severity of coronary-artery stenoses. N Engl J Med. 1996;334:1703-8.

2. Tonino PA, De Bruyne B, Pijls NH, Siebert U, Ikeno F, van' t Veer M, Klauss V, Manoharan G, Engstrøm T, Oldroyd KG, Ver Lee PN, MacCarthy PA, Fearon WF; FAME Study Investigators. Fractional flow reserve versus angiography for guiding percutaneous coronary intervention. N Engl J Med. 2009;360:213-24.

3. de Bruyne B, Bartunek J, Sys SU, Pijls NH, Heyndrickx GR, Wijns W. Simultaneous coronary pressure and flow velocity measurements in humans. Feasibility, reproducibility, and hemodynamic dependence of coronary flow velocity reserve, hyperemic flow versus pressure slope index, and fractional flow reserve. Circulation. 1996;94:1842-9.

4. Pijls NH, van Schaardenburgh P, Manoharan G, Boersma E, Bech JW, van't Veer M, Bär F, Hoorntje J, Koolen J, Wijns W, de Bruyne B. Percutaneous coronary intervention of functionally nonsignificant stenosis: 5-year follow-up of the DEFER Study. $J \mathrm{Am}$ Coll Cardiol. 2007;49:2105-11.

5. Pijls NH, Fearon WF, Tonino PA, Siebert U, Ikeno F, Bornschein B, van't Veer M, Klauss V, Manoharan G, Engstrøm T, Oldroyd KG, Ver Lee PN, MacCarthy PA, De Bruyne B; FAME Study Investigators. Fractional flow reserve versus angiography for guiding percutaneous coronary intervention in patients with multivessel coronary artery disease: 2-year follow-up of the FAME (Fractional Flow Reserve Versus Angiography for Multivessel Evaluation) study. J Am Coll Cardiol. 2010;56:177-84.

6. Task Force on Myocardial Revascularization of the European Society of Cardiology (ESC) and the European Association for Cardio-Thoracic Surgery (EACTS); European Association for Percutaneous Cardiovascular Interventions (EAPCI), Wijns W, Kolh P, Danchin N, Di Mario C, Falk V, Folliguet T, Garg S, Huber K, James S, Knuuti J, Lopez-Sendon J, Marco J, Menicanti L, Ostojic M, Piepoli MF, Pirlet C, Pomar JL, Reifart N, Ribichini FL, Schalij MJ, Sergeant P, Serruys PW, Silber S, Sousa Uva M, Taggart D. Guidelines on myocardial revascularization. Eur Heart J. 2010;31:2501-55.

7. Patel MR, Dehmer GJ, Hirshfeld JW, Smith PK, Spertus JA. ACCF/SCAI/STS/AATS/AHA/ASNC/HFSA/SCCT 2012 Appropriate use criteria for coronary revascularization focused update: a report of the American College of Cardiology Foundation Appropriate Use Criteria Task Force, Society for
Cardiovascular Angiography and Interventions, Society of Thoracic Surgeons, American Association for Thoracic Surgery, American Heart Association, American Society of Nuclear Cardiology, and the Society of Cardiovascular Computed Tomography. J Am Coll Cardiol. 2012;59:857-81.

8. Kern MJ, Lerman A, Bech JW, De Bruyne B, Eeckhout E, Fearon WF, Higano ST, Lim MJ, Meuwissen M, Piek JJ, Pijls NH, Siebes M, Spaan JA; American Heart Association Committee on Diagnostic and Interventional Cardiac Catheterization, Council on Clinical Cardiology. Physiological assessment of coronary artery disease in the cardiac catheterization laboratory: a scientific statement from the American Heart Association Committee on Diagnostic and Interventional Cardiac Catheterization, Council on Clinical Cardiology. Circulation. 2006;114:1321-41.

9. Siebes M, Chamuleau SA, Meuwissen M, Piek JJ, Spaan JA. Influence of hemodynamic conditions on fractional flow reserve: parametric analysis of underlying model. Am J Physiol Heart Circ Physiol. 2002;283:H1462-70.

10. Claessens TE, Van Herck PL, Matthys KS, Segers P, Vrints CJ, Verdonck PR. Influence of zero flow pressure on fractional flow reserve. Biomech Model Mechanobiol. 2004;3:48-55.

11. Pijls NH, Van Gelder B, Van der Voort P, Peels K, Bracke FA, Bonnier HJ, el Gamal MI. Fractional flow reserve. A useful index to evaluate the influence of an epicardial coronary stenosis on myocardial blood flow. Circulation. 1995;92:3183-93.

12. Thiele RH, Nemergut EC, Lynch $\mathrm{C} 3 \mathrm{rd}$. The physiologic implications of isolated alpha(1) adrenergic stimulation. Anesth Analg. 2011;113:284-96.

13. Baumgart D, Haude M, Görge G, Liu F, Ge J, GrosseEggebrecht C, Erbel R, Heusch G. Augmented alpha-adrenergic constriction of atherosclerotic human coronary arteries. Circulation. 1999;99:2090-7.

14. Barbato E, Bartunek J, Aarnoudse W, Vanderheyden M, Staelens F, Wijns W, Heyndrickx GR, Pijls NH, De Bruyne B. Alpha-adrenergic receptor blockade and hyperaemic response in patients with intermediate coronary stenoses. Eur Heart J. 2004;25:2034-39.

15. De Bruyne B, Pijls NH, Barbato E, Bartunek J, Bech JW, Wijns W, Heyndrickx GR. Intracoronary and intravenous adenosine 5'-triphosphate, adenosine, papaverine, and contrast medium to assess fractional flow reserve in humans. Circulation. 2003; 107:1877-83.

16. Di Mario C, Krams R, Gil R, Serruys PW. Slope of the instantaneous hyperemic diastolic coronary flow velocity-pressure relation. A new index for assessment of the physiological significance of coronary stenosis in humans. Circulation. 1994;90:1215-24. 